will use enriched uranium in the form of uranium dioxide, and the design provides for the reactor to be refuelled on power by a single charge machine. Work will begin on the Hunterston site immediately.

The Nuclear Power Group is now in the happy position of having won contracts for at least $£ 180$ million worth of work. Power stations built by the group have generated a quarter of the world's nuclear electricity, and the group has the unique distinction of having successfully exported British nuclear technology, in the building of the Latina $200 \mathrm{MW}$ station in Italy. (The other British export was to Japan, and is better not mentioned.) The group is bound to regard this latest order as a guarantee that it will still be in business after the Select Committee on Science and Technology publishes its report on the British nuclear power industry at the end of this month.

\section{Redeploying Scientists}

A Trenchant defence of the British Government's interventionist policy towards industry was given by Mr Anthony Wedgwood Benn, Minister of Technology, when he spoke at Imperial College on October 17. Mr Benn at first seemed eager to show how unexcep. tional intervention in Britain is-. "The great militaryindustrial complex in the United States," he pointed out, "constitutes a public sector of formidable proportions which makes even the most radical British interventionist look like an amateur."

Despite its mildness, however, government intervention was inevitable and essential. In the computer industry, the ministry and NRDC had made available substantial amounts of money, and the next stage of the ministry's policy towards computers would concentrate on applications. Mr Benn hesitated to say where the British computer industry would have been without government support. The ministry's policy towards shipbuilding was openly interventionist, and the aid made possible by the setting up of the Shipbuilding Industry Board would only be made available to yards that would toe the government line by reorganizing or regrouping. In nuclear power, the task of finding the right industrial structure to allow Britain to cash in on the tremendous investment in civil research and development was almost a classic. $\mathrm{Mr}$ Benn gave away little of the Government's attitude towards the Atomic Energy Authority, merely observing that, having solved many of the technical problems it had set out to solve, it now faced some unresolved choices about its future.

Mr Benn did say something about his attitude towards the Government research establishments. There were two approaches, he thought; one would be to group the establishments under some sort of Technological Authority working closely with industry, and identifying and pursuing goals less expensive and more relevant than the US space programme but capable of establishing a tradition of excellence. The other would simply be to say that the establishments had outlived their usefulness, and run them down sharply, closing many in the process. But neither of these approaches would in fact be adopted-instead the ministry intended to pursue a carefully phased programme designed to break down the barriers separating research from production. The integration of research and production had proved to be the secret of industrial success abroad, Mr Benn thought, and it must become a major policy objective in Britain, too. "It would be quite wrong to find work inside Government establishments for its own sake just to keep scientists and engineers employed."

This aim might involve Government laboratories undertaking contract research from industrial firms on a basis of confidentiality. Alternatively, intimate connexions might be developed between establishments and the new large firms which will emerge- the Gas Turbine Establishment at Pyestock and Rolls Royce was an obvious example of this approach. Finally, the ministry would try to make it easier for people to move between the establishments and industry. "What we are engaged on is not just an attempt to transfer the emphasis from defence to civil work-although we are doing that-nor even to change the emphasis between intra-mural and extra-mural - though we shall do that as well, but to secure a re-distribution of more of our qualified scientists and engineers from research, wherever it is done, into design development production, marketing, and above all management."

\section{More Money for Innovation}

THE National Research Development Corporation is learning to live with wealth. Three years ago its borrowing powers were limited to $£ 10$ million; they were then increased to $£ 25$ million, and a few months ago to $£ 50$ million. Last week the Minister of Technology was talking of increasing them yet again. But all this has not gone to the corporation's head, as its annual report for 1966-67 shows. It is the mixture as before-the development of inventions from industry, universities and government laboratories, with a liberal sprinkling of ideas from private inventors, some amusing, some improbable and some downright eccentric. What, for instance, is one to make of a semi-automatic jelly tester?

Increasingly, though, the corporation is becoming involved in industry's own problems, which call for commercial as well as technical judgments. This year 69 new projects have been taken on, against 28 for the 9 months covered by the last report, and the expenditure on development projects is up, to $\mathfrak{£ \cdot 6 5}$ million. Exploitation receipts are also up, from $£ 430,000$ to $£ 793,000$, and the total income is $£ 1,307,000$, against total outgoings of $£ 4,705,000$. As well as the 69 new projects taken on, support was continued for 115 existing projects. The corporation seems so far to have produced only one real money spinner-perhaps surprisingly it comes from the Medical Research Council and the University of Oxford. It is cephalosporin $C$, the antibiotic which the corporation has supported since 1952. Of the total income of the corporation, $£ 493,000$ came from overseas, and cephalosporin accounted for two-thirds of this. The corporation should be grateful to Professor Abraham and Dr Newton of the Sir William Dunn School of Pathology at Oxford, who discovered and isolated cephalosporin. The corporation continued to support the development of hovercraft, and records with pleasure that a patent dispute in the United States was resolved in favour of $\mathrm{Mr}$ Christopher Cockerell, the British inventor of the hovercraft.

There is one new idea in this year's report. The corporation is supporting a project which enables a 